\title{
THE FRESCOES OF SAINT BRUNO OF QUERFURT IN THE MONASTERY OF THE CAMALDOLESE ORDER AT PAŽAISLIS
}

\author{
Mindaugas Paknys
}

\begin{abstract}
This article investigates the story of St Bruno of Querfurt featured in the fresco cycle in the monastery church of Pažaislis at Kaunas, Lithuania. The frescoes were executed by the Italian artist Michelangelo Palloni in the latter half of the seventeenth century. They are to be found in a corridor linking the church with the monastery: eight of them present the story of the saint and three celebrate his apotheosis. The article examines the causes of the circumstances of the appearance of this cycle in the Camaldolese hermitage, the tradition of the veneration of St Bruno in contemporary Poland-Lithuania as well as a detailed iconography of the frescoes.
\end{abstract}

The monastery of Pažaislis occupies a special place in the history of the veneration of St Bruno throughout Europe. The cycle of frescoes painted here is the most extensive presentation of the mission and martyrdom of St Bruno in the history of art. The frescoes were painted in a little corridor joining the monastery with the sacristy and sanctuary of the church. Recent interest in the frescoes is due to fact that the account of St Bruno's mission contains the mention of Lithuania - for the first time in historical sources. This article analyses the ways and reasons of the appearance of the cycle on the story of the saint in Pažaislis and its connection with the Camaldolese Order.

A question naturally arises as to why such an important cycle of frescoes was produced in a Camaldolese monastery distinguished by the particularly solitary life of its hermits and why it did not spread more widely. That was due to the eremitical nature of the Order and insufficient veneration of St Bruno in the Grand Duchy of Lithuania. The cult of St Bruno (or Boniface) spread mostly among the monks adhering to the monastic rule of the Benedictines since St Bruno was a Benedictine and a faithful disciple of St Romuald, the founder of the Camaldolese Order. The cult of St Bruno was more noticeable in the Camaldolese province of Poland-Lithuania because it was in these lands that he conducted his sublime mission and was killed. 
The account of St Bruno's mission is known from a dozen copies of several sources in which his mission and martyrdom are described variously. Due to these inconsistencies late in the sixteenth century St Bruno was recorded twice in the Martyrologium Romanum - as St Bruno (feast day 15 October) and as St Boniface (the name he took upon entering the monastery; his feast day 19 June). ${ }^{1}$ In both cases the hagiographical story also indicates different places of the mission and martyrdom: St Bruno's mission to Prussia and St Boniface's missionary journey to a Russian king. There are certain differences in the description of the process of the mission, the circumstances of the martyrdom and the fate of the remains of the saint. St Bruno's journey to Prussia is described in greatest detail in the German (socalled Saxon and Bavarian) versions, while according to St Peter Damian's Life of Saint Romuald (which served as the basis for the Italian version) the mission reached the lands of a Russian king. The hagiographical mistake was corrected only in the early eighteenth century and the two biographies were joined into one in the official descriptions of the lives of saints. ${ }^{2}$ Nevertheless, even later, the two narrations were presented as separate. Consequently, the story of St Bruno was rendered variously in art works, too.

The Camaldolese were familiar with St Bruno's (among the monks known as St Boniface) mission and martyrdom described by St Peter Damian (1007-1072). The Life Saint Romuald was published for the first time in 1513, and its Chapter XXVII comprised a comprehensive description of Bruno's mission. Some modern historians believe that Romuald's biography by Damian could be the most exact and most truthful. All facts and data relating to St Bruno's mission were carefully collected in the milieu of Romuald who was Bruno's friend and was personally interested in the success of the mission. Having learned about Bruno's martyrdom Romuald himself wished to make a missionary journey and become a martyr. His mission was quite successful (in Hungary he established three monasteries) and he was not martyred. Writing St Romuald's biography St Peter Damian was sure to use the information collected by the Camaldolese and he had to be well acquainted with all the details about the mission.

${ }^{1}$ Martyrologium Romanum. Editio princeps was first compiled by the ecclesiastical historian Caesar Baronius (1538-1607) in 1584. Now the feast day is 9 March.

${ }^{2}$ I. Leonavičiūtè, ‘Šv. Brunono Kverfurtiečio ciklo šaltiniai', 1009 metai. šv. Brunono Kverfurtiečio misija, comp. by I. Leonavičiūtè (Vilnius, 2006), p. 220. The two biographies were joined for the first time by Conrad Janning, cf. Acta Sanctorum, vol. vi: Junii, (Antwerp, 1715), pp. 217-225. 
The hagiographical story about St Bruno had been familiar to the Benedictines long before, but in Poland and Lithuania it achieved popularity only later. At the beginning of the seventeenth century this account was introduced into The Lives of the Saints compiled in these countries. Damian's version gained currency in connection with St Boniface's feast day on 19 June, while St Bruno's hagiographical account (with the feast day on 15 October) was more concise and laconic. The description of St Boniface's mission could be found in nearly all hagiographical narrations of that period. ${ }^{3}$ In the early seventeenth century Piotr Skarga, author of The Lives of the Saints, also knew St Boniface as a disciple of St Romuald. He placed the account of St Boniface's mission on 21 June, immediately after the presentation of St Romuald's life. ${ }^{4}$ This narrative was akin to Damian's story about St Bruno's journey to a Russian king. Meanwhile there was not a slightest hint about his mission to Prussia in The Lives of the Saints by Skarga.

Since the seventeenth century St Bruno's cult had been popularized in Poland and Lithuania by both the lives of saints and the Camaldolese who settled in the country at that time. Their first monastery was set up in Bielany at Cracow in 1605, and it remained a permanent centre of the Camaldolese province of PolandLithuania. Subsequently other Polish and Lithuanian Camaldolese monasteries were founded in Rytwiany (1621), Bielany at Warsaw (1641), Pažaislis at Kaunas (1662), Beniszew (1663), Wygry (1667) and Szancy (1722). The kings did their share in the establishment of Camaldolese monasteries. Sigismund Vasa erected a chapel in the church of Bielany (at Cracow), Władysław Vasa funded the construction of the Bielany monastery at Warsaw, and John Casimir initiated the foundation of the Wygry monastery. The establishment of Camaldolese monasteries was more complicated than those of other monasteries in the cities - in addition to monk maintenance grants finances had to be procured for the construction of monasteries and churches to be built in remote localities.

${ }^{3}$ The descriptions of St Bruno's mission in the publications in Poland and Lithuania in the sixteenth to eighteenth centuries are discussed by J. Nastalska, 'Święty Bruno-Bonifacy w polskim piśmiennictwie historiograficznym i hagiograficznym do końca XVIII wieku', Święty Brunon. Patron lokalny czy symbol jedności Europy $i$ powszechności Kościoła, ed. A. Kopiczko (Olsztyn, 2009), pp. 329-348.

${ }^{4}$ P. Skarga, Żywoty świętych starego i nowego zakonu na każdy dzień przez caly rok, vol. 1 (St Petersburg, 1862), p. 590. 
Since the very appearance of Camaldolese monasteries in Poland-Lithuania the followers of St Romuald - the Five Martyred Brothers and St Bruno (Boniface), killed in these countries early in the eleventh century - had been venerated. The images recounting their stories had often been found in these monasteries. St Bruno was honoured not only in these countries. Thus up till now there is a chapel of St Bruno in the Tusculano monastery of Camaldolese hermits (Sacro Eremo Tusculano) in Frascati at Rome. Its altar picture features St Bruno's decapitation.

The images of St Bruno, however, most often are found in the Camaldolese monasteries of Poland-Lithuania. Thus, in decorating the royal chapel of St Benedict in the church of the Bielany monastery at Cracow next to the principal pictures of St Benedict some minor cycles of pictures illustrating the lives of St Bruno and St Ladislaus, the contemporary benefactor of the chapel Władysław Vasa, were added. ${ }^{5}$

The respect shown to St Bruno in the Bielany monastery of the Camaldolese at Warsaw deserves special mention. Here the cornerstone of a new church was laid in 1669. King, Michał Karybut Wiśniowiecki, supervised the construction. The focal point of the end of the main building work was a solemn procession to Bielany on 19 June 1673 when the image of St Bruno, donated by John Casimir to St John's Collegiate Church in Warsaw, was carried over to the new church. ${ }^{6}$ This special celebration was held in honour of St Bruno namely on his feast day which had been re-established by the Camaldolese in $1656 .{ }^{7}$ The Holy See contributed significantly to this festivity on 21 January 1673 providing it with an office, raising this feast day to the rank of a semiduplex holy day and permitting its celebration throughout Poland-Lithuania. ${ }^{8}$ In the transferred picture St Bruno was shown wearing a white habit and cope, with a mitre on his head and holding a pastoral staff and a palm twig, symbols of his mission and martyrdom, in his hands. Behind the figure of the saint on both sides there were two scenes from his life witnessing the success of his mission - St Bruno undergoing the ordeal of fire and christening a heathen king.

${ }^{5}$ S. Tomkowicz, Bielany (Cracow, 1904), p. 36.

${ }^{6}$ M. Janocha, Kamedulskie Bielany (Warsaw, 2004), p. 37.

7 J.B. Mittarelli, A. Costadoni, Annales Camaldulenses, vol. 4 (Venice, 1759), pp. 361-362.

${ }^{8}$ Officium S. Bonifacii Martyris (Vilnius, 1673) 
Among the honoured guests at Bielany there were two senators one of them was the GDL chancellor Kristupas Zigmantas Pacas, the founder and patron of Pažaislis. ${ }^{9}$ These festivities could have influenced the choice of iconographical scenes for the murals of the Pažaislis church the construction of which began soon, several years later.

The cycle illustrating the story of St Bruno did not appear accidentally: in the latter half of the seventeenth century the veneration of the saint was on the rise. Although his cult did not undergo any changes until the very end of the nineteenth century, it can be stated that it attracted the greatest attention in Poland-Lithuania namely in the latter half of the seventeenth century. The artistic presentation of St Bruno's story like that in Bielany could appear in any other Calmandolese monastery in Poland-Lithuania at that time. In Pažaislis the decoration work then was most intensive and the realizable iconographic programme was most wide-ranging. It is worth noting that the artistic cycle on the activity of St Bruno was produced as an expression of the homage to one of the first followers of St Romuald in these lands rather than an effort to perpetuate the remembrance of the first missionary in Lithuania.

The entire ensemble of Pažaislis was designed and constructed as a typical Camaldolese monastery. Its eremitical character was reflected both in the choice of a secluded area and the iconographic decoration of the church. The monastery was built on a hill surrounded by a river and forests at some distance from the city in uninhabited terrain. The the monastic ensemble comprised not only the church and the monastery proper but also other buildings typical of Camaldolese monasteries: guesthouses, auxiliary quarters, and the hermitage consisting of eremitical huts. Alongside the monastery there were large gardens.

In the decoration of the church the predominating iconographical themes were those of the Camaldolese (St Romuald, St Benedict, St Bruno, Blessed Bogumil, and the first holy hermits) and of the Virgin Mary. The painted or stucco scenes had to remind the monks of the most venerated saints. The cult of the Mother of God was particularly emblematic in Camaldolese monasteries.

The Camaldolese monastery of Pažaislis was built in the last third of the seventeenth century. ${ }^{10}$ The foundation stones of both the church

${ }^{9}$ Mittarelli, Costadoni, Annales, p. 426-428.

10 Valuable information on Pažaislis and its construction can be found in: H. Kairiūkštytė-Jacinienė, 'Pažaislis ein Barockkloster in Litauen', Tauta ir žodis, vol. 1(6) (Kaunas, 1928); Lithuanian translation: Pažaislis, baroko vienuolynas Lietuvoje (Vilnius, 2001); S. Meškauskas, 'Klasztor kamedułów w Pożajściu', 
and the monastery were laid on 20 October 1667 - on the feast of the Visitation of the Blessed Virgin Mary. The construction of the church took several years. The interior of the church was decorated mainly between 1674 and 1685 . The construction of the monastery and other buildings of the ensemble took more time. Attention was focused on the most important and most ornate structure - the church, dedicated to the Visitation of the Blessed Virgin Mary. Work on it was finished early in the eighteenth century, it was consecrated in 1712, while some other structures were built later on.

Construction and ornamentation work was closely supervised in his lifetime by the patron Pacas (d. 1684) He often visited Pažaislis and could easily control the progress of construction and expenses. He himself selected architects, stucco artists and painters. After his death his relative Kazimieras Mykolas Pacas, a knight of Malta, oversaw the construction. Kristupas Zigmantas Pacas had sent him abroad for several years to do his studies and bequeathed him a large part of his wealth.

The ensemble of Pažaislis is not only one of the finest but also one of the best preserved Baroque monuments in Lithuania. The greater part of its artistic values was produced in the last third of the seventeenth century. The architectural uniqueness gives individuality to Pažaislis: a concave plane of the façade of the church, used for the first time in Europe, a rather rare hexagonal plan and a symmetrical axial design of the entire monastery. The combination of stucco, painting and marble make the church an art object not only of Lithuanian but also of European Baroque.

All frescoes featuring the story of St Bruno were executed by the Florentine painter Michelangelo Palloni (1637-1711 or 1713). ${ }^{11}$ The patron was known to have very carefully selected the artist.

Lituano-Slavica Posnaniensia. Studia Historiae Artium, vol. 5 (Poznań, 1991), pp. 95-115; M. Paknys, 'Nowe źródła o artystach w Pożajściu w kręgu mecenatu Krzysztofa Zygmunta Paca', Biuletyn historii sztuki, 2000, no. 1/2, pp. 153-162; L. Śinkūnaitè, 'Baroko pilnatis Pažaislio vienuolyno ansamblyje', Darbai ir dienos, vol. 26 (Kaunas, 2001), pp. 7-28; M. Paknys, Pažaislis. Menas ir istorija (Vilnius, 2005).

${ }^{11}$ M. Palloni's painting is presented most extensively by M. Karpowicz, Działalność artystyczna Michelangela Palloniego (Warsaw, 1967). Incidentally, the author wrongly indicates that the first chapel on the right is that of St Bruno/ Boniface. Actually, this chapel is devoted to St Francis of Assisi; in it there are no frescoes showing St Bruno. 
One of his principal conditions was the requirement that the artist should work alone instead of supervising the work of a group of apprentices. Therefore it is quite believable that Palloni worked alone or with one or two helpers. It must be said that with respect to the whole fresco area the monastery of Pažaislis far surpassed other seventeenth-century architectural monuments of the GDL, and on the whole such lavishly decorated structures had been unknown previously in the country. The church alone had over a hundred fresco compositions of various sizes. The main surfaces of the church were covered with frescoes between 1678 and 1685 . Palloni's frescoes introduced many novelties into the painting of the GDL - the expressiveness of figures, the use of architectural background, and so forth. had not been so persuasive. The painter successfully exploited the space illusion, colour variety, and the play of light and shade. In his frescoes he frequently used broad vantage points, from high to low, and skilfully exploited the obtained effects. Historical seventeenth-century personalities rather than those of a certain plot are often featured in his intricate compositions. Many of these principles underlie the works presenting St Bruno's mission. Palloni left Pažaislis after Kristupas Zigmantas Pacas' death, having completing the greater part of the project (only the frescoes of the cupola, painted in the early eighteenth century, are attributed to Giuseppe Rossi).

Various iconographical themes can be found in this richly frescoed church. The Assumption of the Virgin Mary is striking in the whole church. The themes of individual saints are presented in the chapels, corridors and the rooms of the quire, chapter house, and sacristy. The patrons of the Camaldolese Order and the patron saints of the Pažaislis sponsors are honoured in the chapels. The frescoes of the corridors illustrate the stories of the lives of the first monks who had lived like the Camaldolese in this country. The rooms of the sacristy and the chapter house are decorated with the scenes of the Last Supper and Christ's suffering. Separate apotheosis scenes of saints can be found on the vaults of some rooms.

Different iconographical scenes are presented in two corridors, leading from the sanctuary to the chapter house and sacristy. The scenes painted in the two symmetrical corridors show the first followers of St Romuald in Lithuania. The corridors linking the monastery with the church were used only by monks, and such iconography could be perfectly familiar to them. 
The corridor passing through the sacristy on the southern side of the monastery features a series of frescoes on the life of St Bruno, associated with the first mention of the name of Lithuania. He provided a description of the first disciples of St Romuald (The Life of the Five Martyred Brothers). Later on St Bruno himself suffered the same fate on a missionary journey.

The entrance from the church to this corridor is through a sanctuary door. Already in the sanctuary the fresco above the door concentrates the viewer's attention on St Bruno as a St Romuald's disciple and is a sort of a starting point for the cycle decorating the corridor. The story of the sanctuary fresco is of interest. Palloni painted it decorating the church. In the nineteenth century the church and the monastery were taken over by the Orthodox, and the fresco was painted over. It was restored only in 1983, since its theme was known from the inscription under it: 'St Romuald leads the Polish duke Casimir into Cluny Abbey'. Such an event seems never to have taken place and it appeared as a result of Skarga's desire to interpret and relate the story of St Romuald's life, written by Peter Damian, with the ancient Polish chronicles. Being aware of the monkshood of Boleslaus I the Brave's grandson Casimir in his youth in the Benedictine monastery he surmised that the Slav duke in question was the future king of Poland, Casimir I the Restorer (Odnowiciel). ${ }^{12}$ This solemn motif, uniting the lines of the founder of the Camaldolese Order St Romuald and the pious king of Poland suited the sanctuary very well. In the fresco the duke is shown kneeling devoutly before the abbot of the monastery meeting him. St Romuald seems interceding for the future monk. The other monk in the monastic habit definitely recommending that the duke should be accepted into the monastery could be St Bruno, in Damian's words the most diligent and assiduous of all St Romuald's disciples. ${ }^{13}$ The entourage of Duke Casimir, somehow passively observing the scene, is shown wearing the clothes of the latter half of the seventeenth century. Some of these followers bear certain similarities to contemporary noblemen and even the king.

The frescoes painted in the corridor of the Pažaislis church are focused on two most important events in St Bruno's life - firstly, his mission (the Pope's blessing, departure to pagan lands, a miracle

12 Skarga, Żywoty, vol. 1, pp. 588-590.

${ }^{13}$ Casimir could really have been sent to the monastery to receive education, but his contact with St Romuald is hardly believable. St Bruno perished seven years before Casimir's birth. 
and the baptism of a local duke) and secondly, his martyrdom and cult (an account of his death, veneration of his relics and the church built on the site of his demise). Success in converting the pagans and martyrdom makes the basis for the missionary's sanctity. Palms leaves, crowns, lilies, etc. as symbols of martyrdom are characteristic stucco ornaments of the vaults and of the walls below them.

There are eleven frescoes in the corridor, eight of them, high on the wall at the vaults, tell the story St Bruno, and three scenes of the traditional apotheoses of saints are painted on the ceiling. The fresco cycle on the life St Bruno begins with the fresco on the western wall of the corridor at the entrance into the monastery and ends with the fresco on the southern wall above the same entrance. The three frescoes on the vault of the corridor are apotheosizing, attesting to the happy end of the saint's earthly life. The other eight frescoes illustrate the mission, martyrdom and glorification of St Bruno after his death.

1. Pope Sylvester II Ordains St Bruno Archbishop. In actual fact, St Bruno was merely authorized by the Pope to preach Christianity in pagan lands. This historical fact was known as having taken place in Rome in 1002. St Bruno was elevated to the bishopric a little later - in 1004 by the archbishop of Magdeburg. However, in the seventeenth century Damian's information was considered most accurate - in his own biography he incidentally wrote that St Bruno went to Rome and the Pope consecrated him as archbishop. Therefore the first scene shows St Bruno's consecration. Visits to the Pope are seen in two more frescoes, and they are easily recognizable by a typical Pope's clothing and the same interiors. The chapel of St Francis of Sales has the fresco St Francis of Sales Visits the Pope, and the other fresco Blessed Bogumil Refuses an Archbishopric in the Presence of Pope Alexander III in the corridor leading towards the chapter house.

2. St Bruno Sets out on Missionary Journeys. In this connection Damian wrote: 'An old monk, who accompanied St Bruno up to the walls of Ravenna, told me that this honourable man, with all the others who followed him, went all the way on foot and unshod singing hymns and even leaving others behind'. The painter of the fresco precisely conveys the meaning of these words. The saint is shown leading the way, gesticulating with his hands as if singing. The horse led behind the missionary shows that although the saint has the choice he prefers a more difficult way of travelling on foot. Such is the beginning of the journey, and later on, the voyage becoming more difficult and the weather getting colder, according to Damian's account, St Bruno nevertheless had to ride on horseback. 
3. 'St Bruno Preaches the Gospel to a Pagan King'. ${ }^{14}$ The saint is shown on a hill facing a king and his heathen followers. The painter Palloni again tries to convey the moods of the personages - St Bruno is shown emotionally persuading, the king is noticeably interested and the heathens surrounding him are astonished. It is worth noting that the painter ignored Damian's remark that when the pagan king was surprised to find that the missionary's clothes seemed to him shabby, St Bruno put on his ornate episcopal robes. In all Pažaislis frescoes St Bruno is depicted wearing a modest white Camaldolese habit. Meanwhile the heathens are dressed in the clothes of the Commonwealth gentry of the second half of the seventeenth century. Such was Palloni's manner of painting historical themes.

4. St Bruno's Ordeal of Fire. This is one of the most impressive frescoes of the cycle. Here the painter recorded a most important episode of the mission - a miracle performed by the missionary when at the request of the king he passed between two bonfires and was unharmed. The fresco again demonstrates the painter's remarkable ability to express the moods of the figures. In the picture the emotions vary greatly - from St Bruno's belief and resolution to the amazement and even fear of the pagans to absolute serenity radiating from the missionary's companion. The theme is presented in the architectural background with the easily recognizable cupola of the cathedral of Palloni's native Florence. This setting, having nothing to do with historical reality, imparts solemnity to the plot. In this cycle the background, painted for the sake of solemnity, is found only in two frescoes - in both cases in the frescoes dealing with miracles - the ordeal of fire and the miracle at St Bruno's relics.

5. St Bruno Baptizes the Pagan King. The scene unfolding the success of the mission is quite temperate and calm. The king clad in a robe is kneeling in the very centre of the fresco. The central axis is accentuated by the ruler's submissively bowed head, St Bruno's baptizing hand and the rays of the sun from above, symbolizing that the act of baptism is taking place not without the interference of the Divine. The centre of the composition is occupied by the missionaries dressed in white Camaldolese habits. In his account of St Romuald's life Damian did not indicate the number of the companions who followed the saint in his mission. In the whole fresco series cycle

${ }^{14}$ Damian calls the ruler met by St Bruno a Russian king. In the Saxon version he is a Prussian king, meanwhile Wipert calls him the Prussian king Netimer. In this article, for the sake of objectivity, he is simply referred to as a pagan king. 
St Bruno is attended by one follower, except this fresco in which he is followed by two Camaldolese. The king's retinue consists of two followers on the right who seem doubtful about the whole idea and they are in contrast with one hardly visible follower with his piously clasped hands. As we know the king's disposition towards the missionary was insufficient, and he met his death namely at the hands of those in the king's milieu who were suspicious or set at variance. Damian also noted that the saint managed to make numerous converts before his martyrdom. The painter describes the religious stratification of the pagan community through these figures.

6. The Beheading of St Bruno. This fresco is the most dramatic of the entire cycle. St Bruno preaching Christianity in the pagan land was murdered on the orders of the king's brother. He is shown on the right side of the fresco in front of a group of pagans. The gesture of his hand clearly indicates who is giving instructions on the procedure to be followed. The decapitated St Bruno and his executioner are in the centre of the fresco. This manner, peculiar to Baroque art, strengthens the tragic impression of the event. The Saxon Version describes St Bruno's death differently. The servants of the king's brother found the saint saying Mass at the altar. One of them took his sword and cut off St Bruno's hand which miraculously continued celebrating. The other servants beheaded the saint and threw his head into the river. It is namely in this version that the Prussian (not Russian) king is named Netimer and his brother, the killer of St Bruno, Zebeden. Nevertheless, while dealing with Pažaislis frescoes one should not forget that they were based on Damian's account, according to which St Bruno carried on missionary work among the Russians; consequently, it would be incorrect to refer to the fresco personages by the aforementioned names.

7. A Miracle at St Bruno's Relics. Damian informs that after St Bruno's slaughter the king's brother became blind and was paralyzed together with the others. When the king saw the miracle he prayed fervently at the saint's relics until those struck with paralysis recovered, believed in God and repented of their sins. The subject of the fresco is the final stage of the story - the king's brother is kneeling at the coffin of the saint and asking forgiveness. Like in the fresco St Bruno's Ordeal of Fire the painter adopted a more solemn architectural background and placed the remains of the saint in a luxurious Baroque sarcophagus. Palloni's intentions of showing the emotions are also visible in this fresco. The king's brother is depicted in the same way as the founder of the monastery Pacas 
himself, watching the scene of the decapitation of St Christopher and praying to his patron saint. ${ }^{15}$ However, the humility and submission of the king's brother are expressed more cogently - he is leaning forward and his stretched right hand imparts internal tension.

8. Building a Church on the Relics of St Bruno. St Romuald's biography by Damian contains a mention about building a church by converted pagans on the site of the martyrdom. On the left side of this fresco there is a group of figures building the church and on the right a partially built church. The fresco has been preserved poorly; therefore it is difficult to identify the personages. A similar fresco is found in the other symmetrically built corridor - there a cycle of frescoes illustrates the life of Bogumil the Blessed. The personages presented in the fresco Blessed Bogumil Builds the Church of Dobrowa can be directly identified as the architect, the Camaldolese and construction organizers at the time of the fresco painting (1678-1685). ${ }^{16}$ It is probable that a group of contemporaries could also be painted in the fresco of the construction of the church over St Bruno's grave. The two last frescoes of the cycle deal with the events after St Bruno's death and with his veneration. In both of them the clothes of the figures and the styles of buildings are in keeping with the fashions and architectural styles of the painting time. Thus, the events of the eleventh century and the tradition of the veneration of St Bruno in the latter half of the seventeenth century are brought somewhat closer together.

The fresco cycle on the life of St Bruno is unique in iconographic terms. In its creation no former specimens of the representation of the saint were used. The most important events in the saint's life and martyrdom were selected independently. Moreover, later as well, due to the eremitical character of the Camaldolese Order this cycle was not copied or used as an iconographical example.

Discussing the series of frescoes on St Bruno attention should also be drawn to the other cycle painted in a symmetrically built corridor. The northern corridor, leading from the sanctuary to the monastery through the chapter house, is devoted to Blessed Bogumil.

${ }^{15}$ In greater detail about this fresco in St Christopher's chapel, see M. Paknys, 'Postać fundatora w fresku Michelangela Palloniego w Pożajściu', Artyści włoscy w Polsce (Warsaw, 2004), pp. 293-299.

${ }^{16}$ It is highly probable that the fresco shows the regular architect of Pažaislis Pietro Puttini; see M. Paknys, 'Nowe źródła o artystach w Pożajściu w kręgu mecenatu Krzysztofa Zygmunta Paca', Biuletyn historii sztuki, 2000, no. 1/2, pp. 153-162. 
This Gniezno archbishop who died in the early thirteenth century resigned his high post and lived the life of the hermit to the end of his days. Since the early seventeenth century his biography has often been presented in Camaldolese texts as an example to be followed. He was venerated not only in Pažaislis but also in other Camaldolese monasteries of Poland and Lithuania. ${ }^{17}$ The first four frescoes illustrate the miracles performed by Blessed Bogumil (miraculously taking parishioners across a river, calling the fish, feeding people with this fish, and miraculously covering a long way to Gniezno). The other four frescoes feature the ecclesiastical career of the blessed (his consecration as archbishop, construction of the church, resigning as archbishop, and leaving Gniezno). ${ }^{18}$

By the way, there is a supposition that originally the theme of the Five Martyred Brothers - the first followers of the Camaldolese in Poland - rather than of the Bogumil the Blessed was selected for the second corridor. The Five Martyred Brothers were extremely popular in all Camaldolese monasteries in Poland and the Grand Duchy of Lithuania: their veneration can sometimes be found in other monasteries throughout Europe. Their cult began to spread soon after the establishment of the first monastery in Cracow early in the seventeenth century. It was a kind of symbolic connection of

17 At the beginning of the seventeenth century Bogumil the Blessed was considered an example to be followed by the first Camaldolese. Thus his detailed biography was presented by Marcin Baronius in his Vitae, gesta et miracula sanctorum Quinque Fratrum Polonorum eremitarum Casimiriensium Ordinis S. Romualdi Abbatis camaldulensium (Cracow, 1610), pp. 34-36. In the historical researches of the Camaldolese Order the Five Martyred Brothers, St Bruno and Bogumil the Blessed are referred to as the early Camaldolese forerunners in these regions. Cf. L. Zarewicz, Zakon kamedułów, jego fundacye i dziejowe wspomnienia $w$ Polsce i Litwie (Cracow, 1871), p. 18.

18 Recently the researcher of the Pažaislis paintings Dr Laima Šinkūnaitè published an erroneous hypothesis stating that the fresco cycle features the hagiographical history of St Adalbert. See L. Šinkūnaite, '1009 metai ir Pažaislis. Krikščioniškuju misijų tema’, Soter, 2000, no. 3 (31), pp. 75-84; L. Šinkūnaitè, 'Pažaislio vienuolyno dekoro ikonografine programa: nauji tyrinejjimų aspektai', Lietuvos Didžiosios Kunigaikštystès barokas: formos, i̇takos, kryptys (Vilnius, 2001), pp. 7-26. The error of this attribution was demonstrated by the author of this article (see M. Paknys, 'Pal. Bogumilas Pažaislio freskose', Naujasis Židinys, 2002, no. 6, pp. 315-322). Nevertheless, Šinkūnaite disregards the arguments and continues to disorient her readership (cf. L. Šinkūnaitè, Šv. Brunonas Kverfurtietis Pažaislio freskose (Kaunas, 2009). The fresco cycle of scenes from the life of Bogumil the Blessed does not contain a single scene of martyrdom or a hostile encounter with the Prussians. Therefore any attribution of the painting narrative to the saint martyr is to be treated as insufficient professionalism. 
the activity of the Camaldolese newcomers with the movement of the first missionaries, the initiators of the eremitical way of life in these lands. In Poland the Five Martyred Brothers were honoured by Wojciech Kadzidłowski by founding a monastery at Beniszew.

The scenes featured in the northern corridor of the Pažaislis complex would have suited perfectly the themes of the Passion which decorate the chapter house. They would also have matched the ideals of the Camaldolese forerunners in these countries - series of frescoes on their activities are seen in the southern and northern corridors. The image King Bolestaw the Brave Visits the First Disciples of St Romuald above the passage leading from the sanctuary to the corridor is related to the Five Martyred Brothers. Meanwhile the fresco St Romuald Ushers the Duke Casimir Vinto Cluny Abbey was a kind of hint about St Bruno's cycle behind the door. However, a different theme - the story of Bogumil the Blessed - was chosen for the northern corridor. It could be assumed that this theme was selected due to its topicality: namely in the latter half of the seventeenth century the process of the beatification the Gniezno archbishop was in full swing. ${ }^{19}$ Incidentally, the same tendency is observed in the choice of other iconographical scenes - St Francis of Assisi and St Mary Magdalene dei Pazzi (they were assigned separate chapels) had been canonized not long ago - the processes of their canonization were completed after the start of the construction in Pažaislis. The choice of St Bruno could also be influenced by the popularity of the feast. The founder's disposition towards the novelties of martyrology would not seem strange if his artistic innovations in Pažaislis are taken into consideration.

This artistic context in which St Bruno appears as one of the first Camaldolese forerunners is presented as a magnificent example for the monks to be followed. The fresco cycle of scenes is arranged as a sequential narrative in which the most important events of the saint's life, martyrdom, and veneration are depicted. Imagine that frescoes two and seven of the cycle are missing. The narrative would lose its continuity and suggestibility, features so highly valued in the Baroque. If the first fresco (the Pope ordains St Bruno archbishop) would be followed by preaching the gospel to the pagan king (third fresco), the transfer of the theme from the papal palace to a distant

${ }^{19}$ The beatification process was taking place in the mid-seventeenth century - on this occasion a special publication was issued; cf. S. Damalevicio, Vita S. Bogumili archiepiscopi gnesnensis eremitae camaldulensis (Rome, 1661). 
heathen province would be barely conceivable. The second fresco (departure for the missions) serves as a link between the two themes. A similar connection is seen in the case of the seventh (the penultimate) fresco. Depicting the building of the church (eighth fresco) after the beheading of the saint (sixth fresco) could suggest that in this way an attempt was made to show that after his death the martyr became a saint or could be venerated as a saint. However, what events were taking place after the saint's death and why was he venerated? The miracle after St Bruno's death, his killer's conversion, and the veneration of his relics (seventh fresco) dispel any doubts and endorse the general line of the narrative. Therefore Palloni's work should be valued both for the masterly execution of the frescoes and for the choice of an excellent narrative design.

The frescoes were painted according to Damian's account of St Bruno's journey to a pagan Russian king. It would be wrong to assume that St Bruno's story was depicted in Pažaislis frescoes due to his being the first missionary on Lithuania's border - the Quedlinburg annals mentioning the name of Lithuania were published much later after the creation of the frescoes in question. Consequently, neither the Camaldolese nor Pacas nor Palloni himself could have imagined that their frescoes could be in any way associated with Lithuania's name. Therefore it would be naïve to believe that the seventeenthcentury fresco cycle was an endeavour to illustrate the first mission namely in Lithuania. St Bruno should first and foremost be treated as one of the first missionaries, a disciple and follower of St Romuald and as an example for the Camaldolese of Poland and Lithuania in the seventeenth century. If the frescoes had had any inscriptions accompanying them, the name of Lithuania would surely have not been found in them. However, that does not diminish the value of magnificent frescoes illustrating real thousand-year-old events.

Translated by Alfoncas Laučka

\section{Author Details}

Dr Mindaugas Paknys is a member at the Lithuanian Institute of Cultural Research. His scholarly interests are the cultural history of the GDL of the 16th to 18th centuries and the history of the Lithuanian religious art of the 16th to 19th centuries.

Address: Lietuvos kultūros tyrimų institutas, Saltoniškių 58, Vilnius LT-08105, Lithuania

Email: pakniai@gmail.com 


\title{
ŠV. BRUNONO KVERFURTIEČIO FRESKOS \\ PAŽAISLIO KAMALDULIŲ VIENUOLYNE
}

Santrauka

\author{
MINDAUGAS PAKNYS
}

Pažaislio vienuolyno bažnyčioje nutapytas freskų ciklas yra, kiek žinoma, detaliausias pasakojimas apie šv. Brunono misiją ir kankinystę dailèje. Kamalduliai buvo susipažinę su šv. Petro Damianio (1007-1072) šv. Romualdo biografijoje aprašyta šv. Brunono (vienuolių vadinamo šv. Bonifacu) istorija. Apaštalų Sostas $1673 \mathrm{~m}$. sausio $21 \mathrm{~d}$. Officium šv. Brunono minejjimo dienai suteikè semiduplex šventès rangą. XVII a. daug dėmesio šv. Brunonui buvo rodoma ir kituose Lenkijos bei Lietuvos kamaldulių vienuolynuose. Tad galima teigti, kad šv. Brunono istoriją vaizduojantis ciklas Pažaislyje neatsirado atsitiktinai.

Visas šv. Brunono istoriją pasakojančias freskas sukūre tapytojas Michelangelas Palloni (1637 - tarp 1711-1713) iš Florencijos. Pagrindines bažnyčios patalpas sienine tapyba jis dekoravo 1678-1685 m. Gausiai freskomis papuoštoje bažnyčioje ištapytos įvairios ikonografinès temos. Visoje bažnyčios tapyboje ryškus Švč. Mergelès Marijos išaukštinimas. Koplyčiose, koridoriuose, choro, kapitulos ar zakristijos patalpose plètojamos atskiros konkrečiu šventujų ikonografinès temos. Dviejuose koridoriuose, jungiančiuose vienuolyno patalpas su bažnyčia, nutapytos pirmuju vienuolių, gyvenusių mūsų krašte pagal kamaldulių pavyzdi, istorijos. Šiaurinio koridoriaus freskose vaizduojama pal. Bogomilo istorija, o pietiniame koridoriuje nutapytas šv. Brunono freskų ciklas.

Iš viso pietiniame koridoriuje yra 11 freskų: aštuonios jų, pasakojančios šv. Brunono istoriją, nutapytos aukštai ant sienų prie pat skliauto, o ant lubų trijose scenose tradiciškai vaizduojamos šventujų apoteozès. Pirmoje freskoje vaizduojamas popiežiaus Silvestro II arkivyskupu išventinamas šv. Brunonas, antroje - šv. Brunono išvykimas i misiją. Kitose trijose freskose vaizduoja sėkminga šv. Brunono misija - pamokslavimas pagonims, šv. Brunono išbandymas ugnimi ir pagonių karaliaus krikštas. Trys paskutinès freskos vaizduoja šv. Brunono kankinystę ir pagerbimą po mirties - šv. Brunono nukirsdinimą, stebuklą, ìvykusį prie jo palaikų, ir virš jo kapo statomą bažnyčią.

Pažaislio šv. Brunono istoriją vaizduojantis freskų ciklas unikalus ikonografiniu požiūriu. Jị kuriant nebuvo naudojamasi ankstesniais šventojo vaizdavimo pavyzdžiais. Savarankiškai buvo atrinkti svarbiausi šventojo gyvenimą ir kankinystę reprezentuojantys momentai. Kadangi kamaldulių vienuolija gana uždara, šis ciklas niekada nebuvo kopijuotas ar naudotas ikonografiniu pavyzdžiu daileje. 